\title{
レーザー微細加工技術を用いた人工関節の開発
}

\author{
吉川 秀樹，菅本 一臣 \\ 大阪大学大学院 医学系研究科 (テ565-0871 大阪府吹田市山田丘2-2)
}

\section{Development of Human Joint Prosthesis by the Process of Metal Surface Using Laser Scanning}

\author{
Hideki YOSHIKAWA and Kazuomi SUGAMOTO \\ Osaka University Graduate School of Medicine, Orehopedic Department \\ 2-2 Yamada-oka, Suita, Osaka 565-0871
}

(Received June 15, 2003 )

\begin{abstract}
The bonding between a metal surface of a human joint prosthesis and a bone is not perfect. It makes the loosening of a metal component from a bone. Porous coating method is widely used to have a rough metal surface, but it cannot regulate the shape of a metal surface. It cannot make enough bonding. Our method is a new metal processing method using a laser scanning for a joint prosthesis, which was developed in Osaka Univ. Graduate School. The metal surface with a microscopic canal structure, which was processed by a new method, has a few times bonding strength compared to a porous coated surface. A new bone invasion was observed in all cavities of the canals. The results encourage the development of a new joint prosthesis which has no loosening from a bone.
\end{abstract}

Key Words: Laser scanning, Human joint prosthesis, Metal surface, Metal process

高齢化社会の到来にともない社会の要求も大きくかわ りつつある．高齢者の健康な生活を提供することはその なかで最も重要なひとつである，我々医療従事者，特に 整形外科医師にとっては痛みのない十分な動きをもつ骨 関節機能をいかに保ち続けるかがその要求に答えるもの といえるであろう。

例えば70才以上の高齢者でからだのどこにも痛みがな い人は皆無であるしまたレントゲン写真で骨関節に全く 変形がない人もまた皆無である。整形外科医院，整骨院 等で治療を受けておられる人の多さを見るとそのニーズ が実感できる.

\section{1. 変形性関節症}

これらは主に加齢による骨関節の変性，それによる変 形が原因と考えられており「変形性関節症」という疾患名で 加療されている. (Fig. 1, Fig. 2) 治療内容としては変性, 変形した骨関節を新しいものにすることは不可能であ り，現在の治療方針は変性，変形した骨関節により引き 起こされる炎症，痛みを投薬，注射等でおさえることを 目的とされている。これは根本治療ではなくあくまでも 対症療法(症状のみをおさえる治療)といえるであろう。

しかし変性，変形が重度に及ぶものではこれらの治療 は無効である。このようなものを解決する糸口として医 療分野で先端医療のキーワードともなっている再生医療
があげられる。これは軟骨/骨をさまざまな細胞工学技術 を用いて再生させる手法である。近年トレンドの遺伝子 治療なども加わり研究面では最も脚光を浴びている領域 である，研究面での注目度は比類のないものであるが, 現時点での治療となるとまだまだ問題は山積した状態で あり，実際に有効な治療にはほとんど至っていない。

Fig. 3は股関節に生じた重度の変形性関節症のレントゲ ン写真である. Fig. 4の正常股関節レントゲン写真では太 ももの大腿骨の先端部(骨頭)はきれいな球形であるのに対

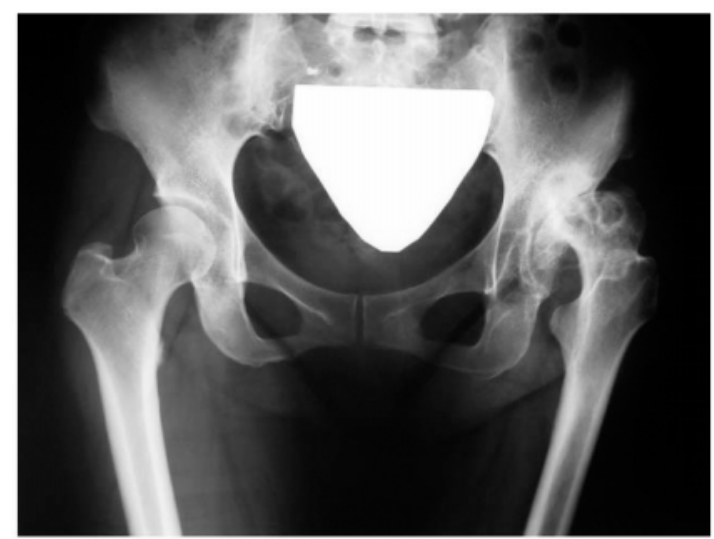

Fig. 1 Radiographic finding in osteoarthritis of a hip joint. Right hip joint shows a typical finding of osteoarithritis. 


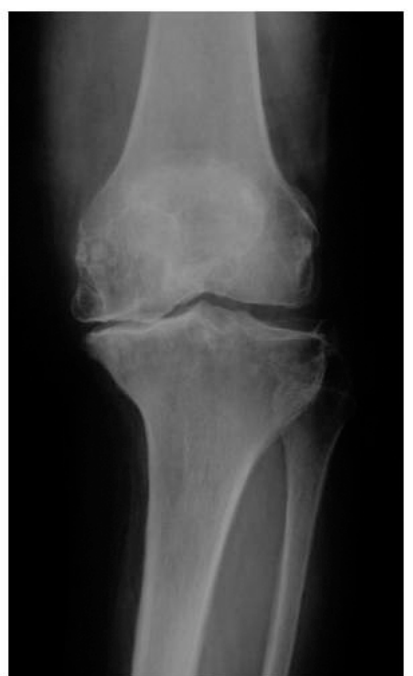

Fig. 2 Radiographic finding in osteoarthritis of a knee joint. Space between two bones is pathologically narrow.


Fig. 3 Radiographic finding and illustration in osteoarthritis of a hip joint. Femoral head is not round and a joint space is narrow.


Fig. 4 Radiographic finding and illustration in normal hip joint. Femoral head is round and a joint space is normal.

して, 変形性関節症の骨頭はいびつに変形しているのが わかる，一方，骨頭の相手となる骨盤の凹みの部分(臼蓋) も同様に正常なものでは球形のくぼみであるのに対し て, 変形性関節症の臼蓋は変形が見られる。関節は人体
の蝶番にあたるところであり真球であってはじめてなめ らかな動きが獲得できるのであり変形の強い関節ではと うてい痛みのないスムーズな動きは得られない.

\section{2. 人工関節置換の概要}

現在, この重度の骨関節の変性, 変形を解決する方法 としては, 人工関節置換という方法があり, 現時点での Gold standardの治療法である．30年以上の治療の歴史があ り，その治療効果は十分に評価されている。 その治療概 要について股関節を例にとって解説する。

人工関節置換では変形した骨頭部分を切除した後, 残 された大腿骨に金属で形成された柄付きの球体を挿入す るものである。残された大腿骨の断面は中空の円柱状で ありこの中空部分に球体を先端に持つ柄を挿入すること となる。一方対する臼蓋部には凹んだ球形の金属をはめ 込むことになる。このようにして変形した関節に対し て，相対する骨の表面に金属を設置し，直接骨どうしが 接触せずかつスムーズな動きがえられる。ただし，直接 金属どうしが当たり傷付かないように互いの金属の間に 強化ポリエチレンの介在物を挿入している。（Fig. 5)

以上が人工関節置換の概要である。これは股関節以外 の関節でも原理はほぼ同じであり，あくまでもあい接す る骨関節の表面に金属を設置し，その隙間に強化ポリエ チレンの介在物を挿入する構造となっている.

では人工関節置換の需要はどの程度のものであるだろ う. 先述した変形性関節症は股関節，膝関節で多く見ら れるものであり，ほかに足関節，肩関節，时関節などで も見られる疾患である．人工関節置換の手術症例として は股関節，膝関節で3万例/年ずつ，他すべてで数千例/年 である。他に股関節の重症骨折例でも人工骨頭と称する 大腿骨側のみの人工物を挿入することが非常に多いが, これらをすべて合計すると年に10万例以上が行われてい る。全世界では正確なデー夕はないがこの10倍以上はゆ うに行われているであろう.

次にこれにかかる医療材料費について述べるが，一例 当たり 80 万円程度である。よって材料費のみで国内で約 1000 億円/年程度の市場となる。これに入院費，薬剤費な


Fig. 5 Postoperative radiographic finding and illustration (left and center) in total hip joint replacement, and a hip prosthesis (right). 
どを含む医療費の合計は莫大なものである。

よってこれほどまでに高額の医療費を必要とするもの であるから, 治療効果についてさらに高いものが求めら れている．また，それを解決すべく様々な研究が行われ ている. 次に現在の人工関節の問題点について述べる.

\section{3. 人工関節の問題点}

人工関節において克服しなければならない問題点は多 岐に亘る。しかし，その中でも最大の問題点は人工関節 の骨に対するゆるみであることは多くの整形外科医が認 めることである。挿入した人工関節が初期には非常に良 好であったものが10年の長い歳月を経てゆるみが生じる のである。このゆるみは臨床的には痛み，歩行困難と なって症状があらわれるためにそれらの問題を解決する 際には再手術を行い技術的に困難となる再人工関節置換 を行わなければならなくなる。（Fig. 6)

ではゆるみはどのような原因で生じるのであろうか. これも様々な研究報告があるが必ずしも明らかにされた わけではない。その原因として強化ポリエチレンの磨耗 粉による骨反応性の融解なども挙げられるが, やはり金 属/骨の間の固着力が最も重要と考えられている．10年の 長い歳月の間に人間が歩行する距離は日に数キロとして 一万キロとなるかもしれない。その間に股関節の屈伸は 数千万回行われる計算になる。 その屈伸運動に際して生 体の関節は単純な蝶番関節ではなく複雑な回旋運動も加 わることとなる。よって，骨の中空部分に挿入された金 属柄部分には骨との間でねじれや沈み込み方向への複雑 な力が加わる。これが何千万回と行われることとなり， その間のゆるみは当然扔こりうるものと予想されるであ ろう。十年以上の長期に亘って金属/骨間の十分な固着力 の保持が求められている.

\section{4. 金属/骨間の固着}

金属/骨間の十分な固着力を得るために骨セメント (POLYMETYL-METHACRYLATE) を金属と骨の接触部分 に充填する方法が1960年代末ょりとられてきた。しか


Fig. 6 Radiographic findings in loosened hip (right) and non-loosened (left) prosthesis.
し, 再手術時の切除の困難さ, 細胞毒性の問題や骨セメ ントといえどもやはりゆるみが生じることより，近年は 骨セメントを用いず直接金属表面に凹凸を持たせて (rough surface) 骨との固着性を得る方法がとられてきた1-3).その 方法として1. Powder sintering, 2. Pressure sintering, 3. Plasma sprayingなど様々な方法が考えられ臨床利用されて きた。これらは金属微粒子をビーズ状に金属柄部分に張 り付けたり，噴霧して金属柄部分を coatingし凹凸をつける といった方法である。(Fig. 7)

しかし，これらの方法での二つの大きな欠点が指摘さ れている．1つは金属の微粒子が金属柄から剥がれ落ちる 危険性である。微粒子は金属柄に溶着されておりその方 法に企業各社の独自のノウハウがある。最近ではその危 険性は非常に少なくなってきたと考えられているが，全 くゼロになったわけではない，

もう1つの欠点がさらに重要と考えるが, 微粒子を溶着 させる方法では，その微細な金属表面の形状を十分に制 御することが不可能である. Fig. 7で示すごとく金属表面 の顕微鏡による拡大写真で金属表面は非常にirregularであ ることが確認できる。十分な骨と金属間の固着を極限に まであげることを目指すならばまずその表面形状を完全 に制御できる手法の確立が必要と考えられる。

\section{5. レーザーによる金属表面加工}

我々整形外科医師がレーザー研究専門家に対して解説 することは釈迦に説法のようなものである。レーザーに よる金属表面加工は工学領域では広く知られかつ様々の 領域で応用利用されている技術である。昨年より我々は この技術を利用して人工関節金属表面に加工を行う可能 性を求めて当大学工学研究科電気工学グループ, (株)ヤス オカらと共同研究を行っている.

その開発にあたり求められていることは，1．様々で複 雑な 3 次元曲面を有する人工関節金属表面に加工するこ と，2. 金属表面の微細な凹凸作成が完全に制御されうる こと，3. 加工が金属の疲労，破損強度に影響を及ぼさな いことである。コンピューター制御によるYAG laser scanningを長期試行錯誤することにより, 上記条件をほぼ満足 する加工手技を獲得するに至っている，現在はそれをさ



Fig. 7 Porous coated prosthesis (left) and microscopic finding (right). 
らに発展させて紫外レーザーを用いた精度のよい金属加 工を開発中である4,5).

加工手技の開発と平行して金属と骨との間の固着力の 研究を行っている. 金属表面の加工制御が可能となった 場合にその形状を決定する必要がある。それには金属と 骨との間の固着力がいかなる要素で決定されているかを 明らかにしなければならない。

例えば人工股関節を例にとると骨頭を切除された中空 の円柱状である大腿骨に金属柄を差し込むが, 顕微鏡学 的に見ると平坦な骨表面に凹凸のある金属表面が接した 状態である。(Fig. 8) 挿入後数週間で金属の凹部分に骨侵 入が見られその結果金属と骨との強固な固定が得られ る. (Fig. 9)

金属表面の微細な凹凸形状を決定する上では次のよう なことが求められる１．金属と骨との間の固着力が最大 限に得られる．2．金属の凹部分に骨侵入が最大限に得ら れる. 3. 金属の凹部分に骨侵入が最短時間で得られるこ とである。

以上の与えられた条件を可能な限り満足させる凹凸形 状を決定するにあたり，以下の研究が必要である。

1）織学的検討 顕微鏡視下に骨侵入を観察する.

2）引き抜き強度実験 ラット大腿骨内に挿入した加工済 み金属片の引き抜き強度実験を行う。（Fig. 10）

3）固着のシミュレーション 有限要素法などを用いてコ ンピュータシミュレーションによって固着力をあげる 金属表面形状をきめる.

これらをくり返し行うことにより最終的な形状を決定 する。
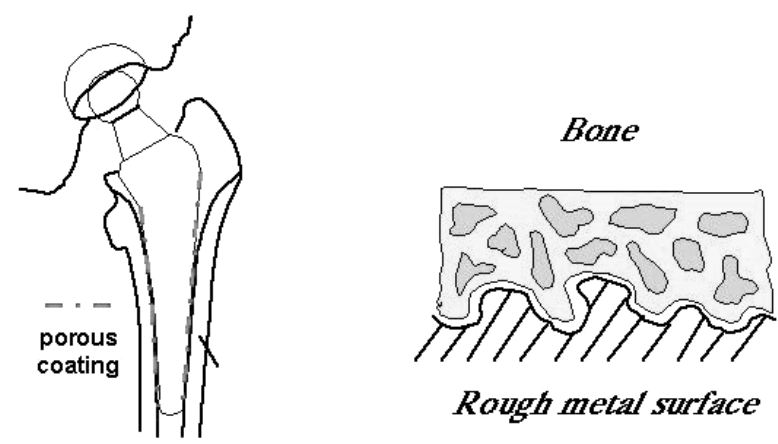

Fig. 8 Illustrations showing macroscopic (left) and microscopic relations between a metal stem and a bone.

Immediately after implantation Lang after implantation
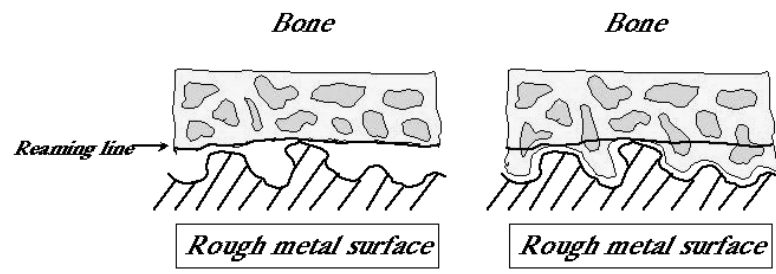

Fig. 9 Illustrations showing microscopic relations between a metal stem and a bone immediately (right) and long (left) after implantation.
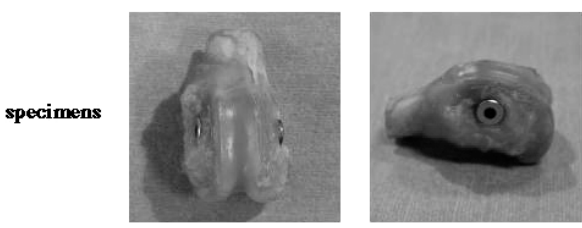

Material testing machine (EHF-F01): SHIMADZU
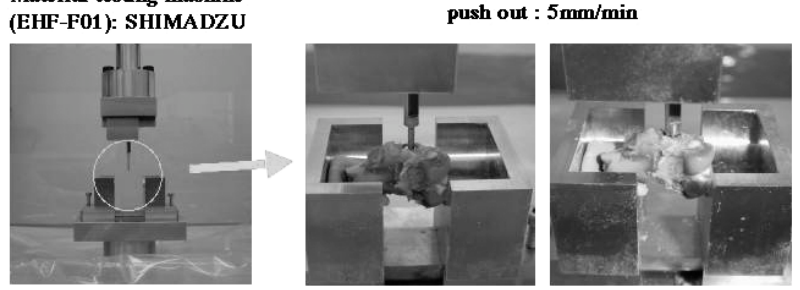

Fig. 10 Pull out test of an implanted metal piece.

\section{6. 金属表面形状の決定}

上述した検討項目をすべて満足する最終的な表面形状 の決定はできていないが，現時点での結果を紹介する。 歩行をはじめとしたさまざまな動作によってかかる力に より金属柄に大腿骨との間で応力が発生する.人間の股 関節でどの方向にどの程度の応力が生じるかの正確な データはないために表面形状の決定に困難をともなう が, 有限要素法などを用いた計算からかかる応力は推定 されておりそれをもとに決定することが理論的には可能 である。

股関節大腿骨内に挿入する金属柄には主に長軸に対し て平行の押し达み力，長軸に対して回旋方向の力などが かかると考えられている．それを考慮して現在金属表面 に格子状の溝をレーザーにて形成し動物実験をくり返し 行い至適形状を決定する試みを行っている。その途中で あるが従来手法であるPorous coating法をはるかに凌駕する データが得られておりその結果を紹介する。

\section{1 組織学的検討}

人工関節素材は一般にCoCr合金，またはTi合金などが 用いられている。 その同一素材で径 $6 \mathrm{~mm}$, 長さ $15 \mathrm{~mm}$ の 金属円柱片を作成した。（Fig. 11）これをラット大腿骨遠位 部に挿入し(Fig. 12)，4週間後に回収した。

Fig. 13左は従来のPorous coating法を施した円柱の組織写 真である. 円形の金属柄の周囲にPorous coatingをおこなわ れた金属粒子が付着している。 その表面は凹凸が不整で あるがその凹み部分に骨侵入が十分に見られている。

一方，Fig. 13右は新技術を施した円柱の組織写真であ る. 円柱の金属表面はレーザー加工を行っている，幅500 $\mu \mathrm{m}$, 深さ $500 \mu \mathrm{m}$ の溝を $3 \mathrm{~mm}$ 幅で長軸に対して 70 度の角度 をつけた溝を加工した。組織写真では金属表面に一定の 凹凸形状が形成されている，また，その凹み部分には骨 侵入が完全に見られている。

\section{2 引き抜き強度実験}

ラット大腿骨内に挿入した金属片の引き抜き強度実験 を行った. 方法はFig. 10に示すように, 手術4週後に左右 


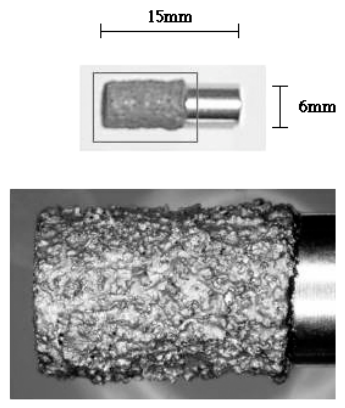

Plasma coating

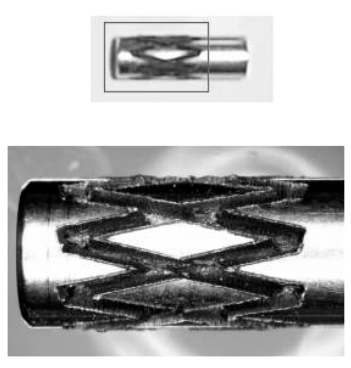

Tartan check $(500 \mu \mathrm{m})$
Fig. 11 Porous coated (right) and new developed (left) metal pieces.

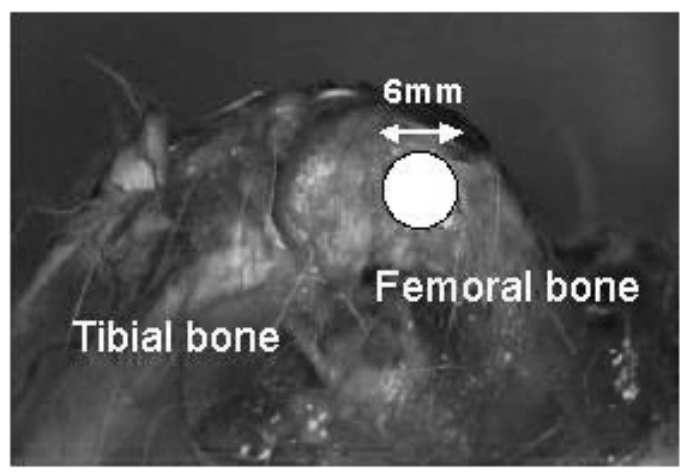

Fig. 12 Implantation of a metal piece into a distal femoral bone of a rat.
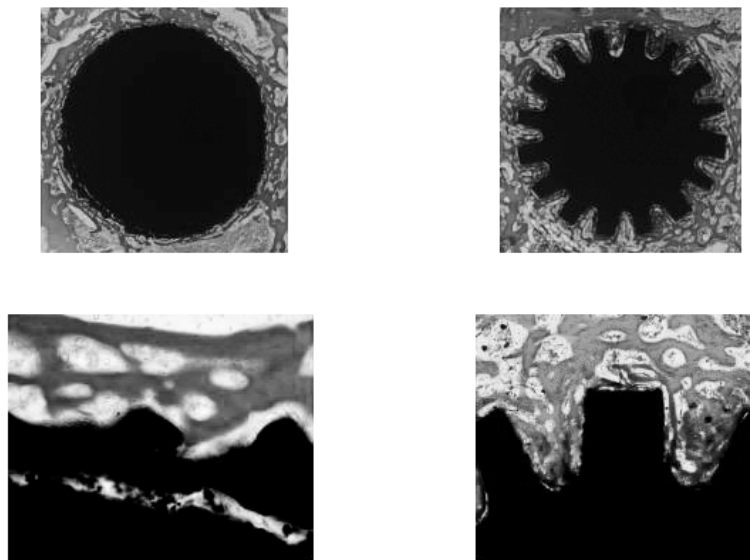

Plasma coating



Tartan check $(500 \mu \mathrm{m})$

Fig. 13 Microscopic findings of porous coated (right) and new developed (left) metal pieces and surrounded bones.

の大腿骨遠位部分をポリメチルメタクリレート (PMMA) を用いて固定し，島津社製 (EHF-F01) マテリアルテスティ ングマシーンを用いて金属のみを $5 \mathrm{~mm} /$ 分の速さで押し, 金属と骨との間に動きが生じた瞬間の力 $(\mathrm{kg} \cdot \mathrm{N})$ を計測 し，さらにその值を金属と骨との間の有効面積 $\left(\mathrm{mm}^{2}\right)$ で割 り，せん断力 $(\mathrm{MPa})$ を求めた。その結果はFig. 14に示すよ うに, 従来のPorous coating加工群では, せん断力は平均 $2.246 \mathrm{MPa}$ であったのに対して, 新技術加工の群では平均
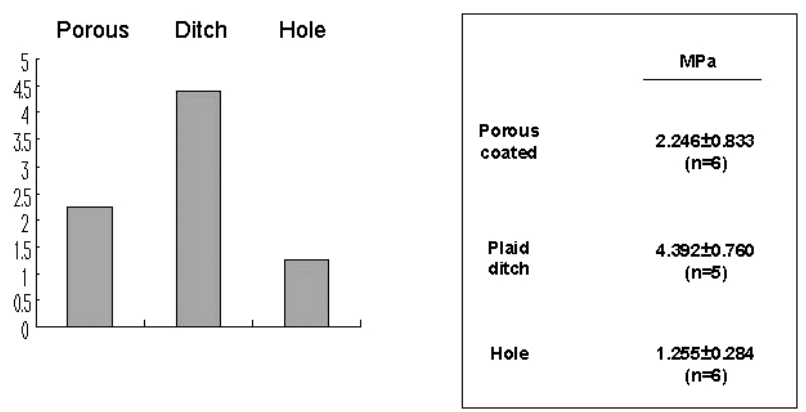

Mann-Whitney U test

Fig. 14 Comparison of bonding strength between porous coated, plaid ditched, and holed metal surfaces.

4.392 MPa と約2倍の高值を示した。また，単純にレーザー にて穴のみを形成した群では1.255 MPaと低值を示した。 以上から今回の新手法のレーザー加工によって金属表面 に溝加工をすることにより有意にせん断力が増加し，従 来のPorous coating加工よりもはるかに強い金属と骨の固着 力を得ることができることが示唆された。これにより人 工関節への応用が十分に期待される結果であると思われ る.

\section{7. 人工関節への臨床応用}

人工関節手術は関節機能を失った患者の多くで機能を 再建させる治療方法として大きな貢献をしてきた．高齢 化社会が進むにつれてその役割はますます大きなものと なりつつある。しかしその反面人工関節の寿命というこ とが大きな問題として取り上げられるようになってから も久しい. その原因の最大のものは人工関節のゆるみで あった。その問題が十分に解決されないまま現在に至っ ている。今回の新手法による金属表面加工はその問題点 を解決する可能性を有するものとして大きな期待が寄せ られる。先述した骨侵入の条件，強度の問題などをさら に検討しなければならないが，これまでporous coating法で は制御できずに風任せであった金属表面形状の決定が新 手法により自由に決定できうるという大きな利点が，こ れらの検討をも可能にされうるので近い将来に問題解決 はされるものと思われる。一臨床医としてこれらのレー ザー技術が革新的治療をもたらすことを期待し，またそ の実現を信じている。本研究は科学技術振興調整費充当 戦略的研究拠点「阪大フロンティア研究機構」で実施され た。

\section{参考文献}

1) R. M. Pilliar: J. of Biomed. Mater. Res. 21 (1987) 1.

2) R. Poss, P. Walker, and M. S. Spector: Clin. Orthop. 235 (1988) 181

3) B. S. Ramamurti, T. E. Orr, and W. H. Harris: J. Biomed. Mater. Res. 36 (1997) 274.

4) Y. Mori and T. Sasaki: J. Cryst. Growth. 156 (1995) 307.

5) Y. Mori and T. Sasaki: Opt. Lett. 21 (1996) 1348. 